\title{
Algal application as a biological control method of root-knot nematode Meloidogyne incognita on cucumber under protected culture conditions and its impact on yield and fruit quality
}

\author{
A. A. S. A. El-Eslamboly ${ }^{1 *}$ (D, Mona M. Abd El-Wanis ${ }^{1}$ and A. W. Amin ${ }^{2}$
}

\begin{abstract}
This study was conducted during seasons 2016 and 2017 to control the root-knot nematode Meloidogyne incognita in cucumber, cultivated in infected soil, using some algal treatments under greenhouse conditions, at Kaha Farm, Qaluobia Governorate, Egypt. Six algal treatments were tested: two foliar applications of Spirulina and Amphora, two drenched soil applications of Spirulina and Amphora, two treatments using Spirulina, as spraying and drenching, and Amphora, as spraying and drenching, in addition to the Rugby nematicide (10\% Ebufos, at the rate of $5 \mathrm{~g} / \mathrm{m}^{2}$ ) and control. Rugby was applied by a soil prepared in its experimental units. After 15 days from transplanting, the algal extract treatments were applied twice monthly for 3 months. The same concentration $(2 \mathrm{~g} / \mathrm{l})$ of both types of algae was applied in both foliar and drench treatments. The control was sprayed only by water. The results indicated that the soil drenched with Amphora or Spirulina extracts had significant increments in vegetative growth, yield, and fruit quality. In contrast, the control plants had the lowest values in all criteria. Amphora (sprayed with soil drenched) treatment gave 2.5 and 2.69 folds the control in marketable yield in 2016 and 2017 seasons, respectively. The combination of sprayed and soil drenched with Amphora was more effective in nematode's control or in enhancing plant resistance for nematode as shown at most nematode parameters, especially the rate of nematode reproduction factor (RF), which reached 0.42 and 0.45 in both seasons, respectively. It had insignificant differences compared with the nematicide. Therefore, using algae for the biological control of root-knot nematodes is recommended, especially in sustainable agriculture for maintaining the soil and improve fertility.
\end{abstract}

Keywords: Algae, Root-knot nematode, Meloidogyne incognita, Control, Cucumber, Yield and fruit quality

\section{Background}

Cucumber, Cucumis sativus L., is one of the cash crops grown worldwide. Plant nematodes cause a great damage in agriculture. In Egypt, they have become dangerous pests in most crops, especially in the newly reclaimed sandy soil. Cucumber is highly susceptible to root-knot nematodes (Sikora and Fernández 2005).

\footnotetext{
* Correspondence: azaz2005asd@yahoo.com

${ }^{1}$ Vegetable Crops Production under Protected Cultivation Research

Department, Horticulture Research Institute ARC, 1 Shooting Club St., Dokki, Giza, Egypt

Full list of author information is available at the end of the article
}

Synthetic nematicides are one of the most effective methods to manage root-knot nematodes. However, their negative potential impact on the environment and ineffectiveness after prolonged use have led to a total ban or restricted use of most nematicides and an urgent need for safe and effective options. Biological control promises to be one of very important alternative methods. Nonchemical and eco-friendly strategies for nematode management such as soil management, organic amendments, fertilization, biological control, and heat are a major economic and environmental acceptable methods to control root-knot nematodes (Collange et al. 2011). Spirulina is a type of blue-green alga 
that is rich in proteins, vitamins, minerals, carotenoids, and antioxidants that can help the plants to produce a good yield and resist the nematodes (Shawky et al. 2009).

Youssef and Ali (1998) mentioned that three species of blue-green algae: Anabena oryzae, Nostoc calcicola, and Spirulina sp. together achieved the highest significant reduction in the number of galls and egg masses of Meloidogyne incognita infecting cowpea and improved plant growth. Culture of the Microcoleus vaginatus (alga) inhibited hatching of $M$. incognita eggs and killed second stage juveniles (Khan et al. 1997). Sharma and Gaur (2008) showed that the extracts and exudates of five cyanobacteria made a significant inhibition of M. incognita. Shawky et al. (2009) recommended the bio-organic application of nematicides against the root-knot nematode in cucumber to reduce the soil and plant polluting by chemical nematicides. Aqueous extract of Spirulina platensis enhanced the control of M. incognita and achieved the highest reduction in the number of the second-stage juveniles in soil, numbers of galls, developmental stages, females, egg masses, and egg numbers/egg mass in roots of cucumber. In addition, all applications significantly improved vegetative growth and increased the yield of cucumber. Besides, they enhanced the soil biological activity, total cyanobacterial count, $\mathrm{CO}_{2}$ evolution, dehydrogenase and nitrogenase activities, and available nitrogen, phosphorus, and potassium that resulted in increasing of soil electrical conductivity and soil $\mathrm{pH}$ reduction. Youssef and Eissa (2014) found that Nostoc, Anabaena, Oscillatoria, Aulosira, and Lyngbya enriched paddy field soil by fixing atmospheric nitrogen and supply vitamin B complex and growth-promoting substances.

Radwan et al. (2012) reported that bio-products made a significant reduction in the root galls and the numbers of juveniles in the soil. Cyanobacteria application on tomato plants had an effect in the prevention of root-knot nematode $M$. incognita and gave a harmful effect of biomass on gall induction (Pushparaj et al. 2000).

Wu et al. (1997) reported the role of betaines in alkaline extracts of the marine brown alga, Ascophyllum nodosum, in suppression and decreasing the fecundity of the tomato root-knot nematode, $M$. incognita. Furthermore, cyanobacterium could be used as a protection agent against $M$. incognita in tomato, as reported by Pushparaj et al. (2000). A. nodosum extracts in the soil decreased the infection of tomato plants by root-knot nematodes and reduced the number of eggs (Massa 2010).

Enan et al. (2016) reported that the foliar application of algal extract, using Spirulina, produced significantly higher values of photosynthetic pigments, vegetative growth, sugar content, quality, minerals contents in leaves, and root yield on the sugar beet. Also, algal extracts promote vegetative growth and crop yield and quality and in addition increase the tolerance to stress conditions (Ghalab and Salem 2001). Moreover, they increase the photosynthetic pigments and improve total carbohydrates, starch, amino acids, and proteins (Yassen et al. 2007). Algae were used on many plants as growth stimulants such as cucumber (Ahmed and Shalaby 2012) and tomato (El-Sayed et al. 2018).

Amphora contained high protein, lipid, and carbohydrate besides the high amounts of essential amino acids (Chtourou et al. 2015). Amphora had antioxidant activities (Lee et al. 2008).

The present study was carried out to evaluate the efficacy of two types of algae through different application methods to manage the root-knot nematode $M$. incognita infecting cucumber plants, and as growth promoters under greenhouse conditions.

\section{Material and methods}

This study was carried out during the two successive seasons of 2016 and 2017 under greenhouse conditions at a highly $M$. incognita-infected soil at the experimental farm of Kaha Vegetable Research Farm, Horticulture Research Institute, Agriculture Research Center (ARC), Qaluobia Governorate, Egypt, whereas the initial nematode populations were 13,752 and 14,124 second-stage juveniles $/ 250 \mathrm{~g}$ soil in the first and second seasons, respectively.

\section{Plant materials}

Cucumber, Hesham hybrid $F_{1}$ (Seminis Seed Company), seeds were sown on the fifth of February in 2016 and eighth of February in 2017 in seedling trays with 84 cells, filled with a mixture of peat moss and vermiculite at the ratio of 1:1 $(v / v)$. Three hundred grams of ammonium sulfate, $400 \mathrm{~g}$ of calcium superphosphate, $150 \mathrm{~g}$ of potassium sulfate, $50 \mathrm{ml}$ of nutrient solution, and $50 \mathrm{~g}$ of a fungicide were added for each $50 \mathrm{~kg}$ of the peat moss in the greenhouse nursery. Seedlings were transplanted to a greenhouse, on March 9, 2016, and March 12, 2017. Seedlings were transplanted into two rows in the bed (row $7 \mathrm{~m}$ length and $1.0 \mathrm{~m}$ width). The space between the plants was $0.50 \mathrm{~m}$. The experimental unit contained 15 plants in each row. The conventional agricultural practices, i.e., irrigation, fertilization, weeding, and pest control, followed the standard commercial practices and were carried out as recommended by the Ministry of the Agriculture in Egypt, for cucumber production.

\section{Time of application}

The experimental treatments, each with three replicates, were as follows: sprayed with Spirulina platensis, soil 
drenched with S. platensis, sprayed with Amphora coffeaeformis, soil drenched with A. coffeaeformis, sprayed and soil drenched with $S$. platensis, sprayed and soil drenched with $A$. coffeaeformis, soil drenched with contact action nematicide, Rugby (organophosphates group $10 \%$ Ebufos), as a granule at the rate of $5 \mathrm{~g} / \mathrm{m}^{2}$, as well as control. Two weeks after transplanting, the first foliar application was executed by spraying the cucumber plants, using alga extracts once biweekly, which continued for 3 months. The soil addition (drench) treatments were performed at the same time, while the Rugby nematicide was performed by a soil prepared in its experimental units. The recommended concentration of both types of alga $(2 \mathrm{~g} / \mathrm{l})$ was applied in both foliar or soil drench treatments. The control plant was sprayed only with water in all times.

\section{Algae extract}

The ready-made algal extract was obtained from Algal Biotechnology Unit, National Research Centre (NRC), Giza, Egypt. The blue-green alga, Spirulina platensis, belonging to Cyanophyta, and Amphora cofeaeformis were massively produced at the Algal Biotechnology Unit, NRC in continuous cultures. Algal extracts were prepared as previously described by Enan et al. (2016).

The alga A. cofeaeformis was locally isolated from the Egyptian irrigation water. Previous studies concerned with this alga focused on fish and animal nutrition. Regarding plant nutrition, recent studies are running on its high contents of polysaccharides, amino acid, and phytohormones. Amphora supposed to have a positive effect on the plant nutrition that overcomes the adverse effect of biotic stress as it contents have amino acids, proteins, and plant hormones.

\section{Studied characteristics Horticultural characteristics}

\section{A. Vegetative growth characteristics}

Vegetative growth characters were recorded 75 days after transplanting of three plants randomly chosen from each plot as follows: (a) plant length $(\mathrm{cm}),(\mathrm{b})$ average internode length $(\mathrm{cm})$, (c) number of leaves per plant, (d) stem diameter $(\mathrm{cm}),(\mathrm{e})$ number of branches/plant, (f) plant fresh weight (g), (g) number of days to flowering, (h) fruit set percentage, and (i) leaf area $\left(\mathrm{cm}^{2}\right)$.

Leaf area $\left(\mathrm{cm}^{2}\right)$ was expressed as the mean leaf area in square centimeters, using the fresh weight method. The leaves were cleaned from dust and then weighed to the nearest $0.001 \mathrm{~g}$. Therefore, 20 disks of known area were separated as weight

$$
\begin{aligned}
\text { leaf } \text { area } \mathrm{cm}^{2}= & \frac{\text { fresh weight of one leaf No.10 }}{\text { fresh weight of } 20 \text { disks }} \times 20 \\
& \times \text { area of disk }
\end{aligned}
$$

where the area of a disk is about $1.0 \mathrm{~cm}$.

B. Yield and its components

Yield and its components are as follows: (a) total weight of fruits /plant, (b) total number of fruits/plant, (c) early yield (kg/plant), (d) early yield (number/plant),

(e) total yield (ton/greenhouse), (f) marketable yield, and (g) percentage of unmarketable yield.

\section{Fruit characteristics}

Fruit characteristics are as follows: (a) fruit length $(\mathrm{cm})$, (b) fruit diameter $(\mathrm{cm})$, and (c) average fruit weight $(\mathrm{g})$.

\section{Chemical analyses}

a. Plant dry weight (g) was measured as the weight of the same plants used for plant fresh weight after being dried out in an oven with driven hot air at 70 ${ }^{\circ} \mathrm{C}$ until a constant weight is achieved.

b. Plant dry matter percentage was measured by this equation:

Plant dry matter $\%=\frac{\text { Plant dry weight }(\mathrm{g})}{\text { Plant fresh weight }(\mathrm{g})} \times 100$

c. Fruit dry matter (\%) was determined by allowing $100 \mathrm{~g}$ of fruit fresh weight to dry in an oven at $70^{\circ} \mathrm{C}$ till a constant weight is achieved.

d. Total soluble solids (TSS \%) were measured in fruit juice by using a hand refractometer, according to the methods of AOAC (2012). Five fruits were taken at random from each treatment for this test.

e. For determination of leaf pigments, chlorophyll content, which used the fifth leaf from the shoots' growing tip, was measured by a SPAD 501 leaf chlorophyll meter (Yadava 1986).

f. Total nitrogen in leaves was assayed in milligrams per gram dry weight by the micro-Kjeldahle method indicated by Pregl (1945).

g. Potassium concentrations in leaves, in $\mathrm{mg} / \mathrm{g}$ dry weight, were determined using a flam-photo metrically, according to the method described by Brown and Lilleland (1946). 
h. Total phosphorus (\%) was determined calorimetrically, according to the method described by Murphy and Riely (1962), as modified by John (1970).

\section{Nematode estimation}

The initial population density in the infested field was estimated by modified sieving and Bearman's plate technique (Viglierchio and Schmitt 1983). At the end of the season, plants were uprooted; roots were washed by tap water and stained by an acid fuchsine (Franklin and Goodey 1959). Numbers of galls, egg masses, and eggs/ plant root were recorded on roots stained with red acid fuchsine.

\section{Experimental design and statistical analysis}

The experiments' layouts were randomized complete blocks design, with three replications. Data were statistically analyzed, using analyses of variance (ANOVA) with the Stat soft statistical package (MSTATC) software program (Michigan State University, East Lansing, MI, USA). Probabilities of significance among treatments and means compared with the least significant difference (LSD) $(P \leq 0.05)$ were used to compare means within and among treatments according to Gomez and Gomez (1984).

\section{Results and discussion}

\section{Algal effects on horticultural characteristics}

\section{Effect of algal treatments on vegetative growth and}

\section{flowering}

Data presented in Tables 1 and 2 showed that the plant and internode length, number of branches and leaves per plant, plant fresh and dry weight, stem diameter, and leaf area of cucumber plants had significant increases than the characteristics of the control in both seasons.
Different algal treatments had insignificant differences in most vegetative characteristics compared with Rugby (chemical nematicide) treatment, except Amphora (spray + soil drench) treatment, which demonstrated a significant superiority in most vegetative characteristics in both seasons compared with the Rugby nematicide and control. These results may be due to some secondary metabolite products such as the hormone components, indoles, cytokinins, gibberellins, brassinosteroids, and other compounds, which are considered as plant growth regulators including amino acids, peptides, and polyamines in Amphora in high concentrations than in Spirulina. This conclusion is consistent with that of Lee et al. (2008), in addition to a higher amount of different antimicrobial and nematicidal actions such as antioxidants, polyphenols, flavonoids, and some enzymes as record by Chtourou et al. (2015).

Finally, all biological treatments showed good effects in the confrontation with chemical nematicide, while Amphora (spray + soil drench) had a significant increment in plant vigor and gave an excellent impact compared with chemical nematicide (Rugby). These results agree with that of Radwan et al. (2012).

Insignificant differences were recorded among the plants regarding the chlorophyll SPAD index, which was measured before treatments' implementation; in contrast, significant increments were observed in this parameter after application compared with the control plants, whereas Amphora (spray + soil drench) improved the chlorophyll content compared with the Rugby treatment. The foliar application of algal extract, using Spirulina, produced significantly higher values of photosynthetic pigments (chlorophyll a and b and carotenoids). These results are likely due to the high contents of algae and their extract of cytokinins and similar substances. The growth promoters' components in algae

Table 1 Effect of algal treatments of cucumber Hesham hybrid compared with control and Rugby nematicide on vegetative growth under infested soil with root-knot nematodes in 2016 and 2017 seasons

\begin{tabular}{|c|c|c|c|c|c|c|c|c|c|c|c|c|}
\hline \multirow[t]{3}{*}{ Treatments } & \multicolumn{6}{|l|}{2016} & \multicolumn{6}{|l|}{2017} \\
\hline & \multirow{2}{*}{$\begin{array}{l}\text { Plant } \\
\text { length } \\
\mathrm{cm}\end{array}$} & \multicolumn{2}{|l|}{ Number } & \multirow{2}{*}{$\begin{array}{l}\text { Stem } \\
\text { diameter } \\
\text { mm }\end{array}$} & \multirow{2}{*}{$\begin{array}{l}\text { Internode } \\
\text { length } \\
\mathrm{cm}\end{array}$} & \multirow{2}{*}{$\begin{array}{l}\text { Leaf } \\
\text { area } \\
\mathrm{cm}^{2}\end{array}$} & \multirow{2}{*}{$\begin{array}{l}\text { Plant } \\
\text { length } \\
\mathrm{cm}\end{array}$} & \multicolumn{2}{|l|}{ Number } & \multirow{2}{*}{$\begin{array}{l}\text { Stem } \\
\text { diameter } \\
\mathrm{mm}\end{array}$} & \multirow{2}{*}{$\begin{array}{l}\text { Internode } \\
\text { length } \\
\mathrm{cm}\end{array}$} & \multirow{2}{*}{$\begin{array}{l}\text { Leaf } \\
\text { area } \\
\mathrm{cm}^{2}\end{array}$} \\
\hline & & Branches & Leaves & & & & & Branch & Leaves & & & \\
\hline Control & 231 & 16 & 45 & 16.5 & 10.3 & 187 & 248 & 15 & 44 & 17.6 & 9.40 & 196 \\
\hline Rugby $10 G$ & 345 & 24 & 61 & 25.5 & 9.8 & 286 & 378 & 28 & 62 & 28.2 & 10.6 & 298 \\
\hline Spirulina spray & 290 & 21 & 52 & 24.7 & 12.1 & 278 & 322 & 24 & 47 & 26.9 & 11.8 & 286 \\
\hline Spirulina drench & 315 & 21 & 54 & 26.2 & 13.5 & 256 & 363 & 24 & 55 & 27.1 & 12.1 & 274 \\
\hline Amphora spray & 320 & 24 & 54 & 25.3 & 12.8 & 294 & 345 & 26 & 57 & 27.6 & 12.5 & 302 \\
\hline Amphora drench & 335 & 23 & 56 & 25.3 & 14.2 & 312 & 370 & 27 & 60 & 26.6 & 12.7 & 321 \\
\hline Spirulina spray + drench & 335 & 28 & 63 & 26.4 & 13.7 & 278 & 365 & 26 & 59 & 27.4 & 14.0 & 287 \\
\hline Amphora spray + drench & 375 & 31 & 66 & 27.6 & 13.9 & 338 & 387 & 33 & 64 & 27.9 & 14.2 & 323 \\
\hline LSD at t 0.05 & 56 & 1.9 & 5.3 & 2.10 & 1.10 & 43 & 42 & 2.1 & 4.8 & 2.20 & 1.40 & 38 \\
\hline
\end{tabular}


Table 2 Effect of algal treatments of cucumber Hesham hybrid compared with control and Rugby nematicide on plant fresh and dry weight, dry matter percentage, chlorophyll SPAD index, number of days to flowering, and fruit set percentage under infested soil with root-knot nematodes in 2016 and 2017 seasons

\begin{tabular}{|c|c|c|c|c|c|c|c|c|c|c|c|c|c|c|}
\hline \multirow{3}{*}{ Treatments } & \multicolumn{7}{|c|}{2016} & \multicolumn{7}{|c|}{2017} \\
\hline & \multicolumn{2}{|c|}{ Plant weight (g) } & \multirow[b]{2}{*}{ Dry matter (\%) } & \multicolumn{2}{|c|}{ SPAD index } & \multirow{2}{*}{$\begin{array}{l}\text { No. of } \\
\text { days to } \\
\text { flowering }\end{array}$} & \multirow{2}{*}{$\begin{array}{l}\text { Fruit } \\
\text { set\% }\end{array}$} & \multicolumn{2}{|c|}{ Plant weight (g) } & \multirow{2}{*}{ Dry matter (\%) } & \multicolumn{2}{|c|}{ SPAD index } & \multirow{2}{*}{$\begin{array}{l}\text { No. of } \\
\text { days to } \\
\text { flowering }\end{array}$} & \multirow{2}{*}{$\begin{array}{l}\text { Fruit } \\
\text { set\% }\end{array}$} \\
\hline & Fresh & Dry & & Before & After & & & Fresh & dry & & Before & After & & \\
\hline Control & 618 & 53.46 & 8.65 & 39.6 & 42.7 & 21 & 58 & 675 & 59.46 & 8.8 & 40.2 & 43.1 & 22 & 52 \\
\hline Rugby 10G & 830 & 77.19 & 9.30 & 40.6 & 48.7 & 21 & 71 & 812 & 71.19 & 8.8 & 41.2 & 47.7 & 21 & 69 \\
\hline Spirulina spray & 690 & 61.66 & 8.94 & 40.1 & 46.3 & 22 & 67 & 711 & 64.70 & 9.1 & 40.6 & 46.8 & 21 & 70 \\
\hline Spirulina drench & 745 & 66.01 & 8.86 & 39.8 & 49.5 & 22 & 66 & 765 & 71.01 & 9.3 & 41.0 & 49.4 & 22 & 68 \\
\hline Amphora spray & 722 & 66.65 & 9.22 & 40.4 & 49.8 & 21 & 69 & 734 & 71.19 & 9.7 & 40.7 & 48.7 & 21 & 71 \\
\hline Amphora drench & 822 & 74.88 & 9.11 & 39.8 & 50.8 & 20 & 72 & 824 & 83.6 & 10.1 & 40.8 & 49.3 & 21 & 69 \\
\hline $\begin{array}{l}\text { Spirulina spray + } \\
\text { drench }\end{array}$ & 802 & 75.23 & 9.38 & 39.9 & 49.7 & 21 & 69 & 789 & 70.23 & 8.9 & 41.5 & 48.2 & 22 & 68 \\
\hline $\begin{array}{l}\text { Amphora spray + } \\
\text { drench }\end{array}$ & 845 & 81.79 & 9.70 & 40.4 & 53.4 & 21 & 75 & 839 & 80.4 & 9.5 & 40.9 & 51.7 & 21 & 72 \\
\hline LSD at $t_{0.05}$ & 42.0 & 7.30 & 0.36 & NS & 3.60 & NS & 3.4 & 33.2 & 8.50 & 0.48 & NS & 2.3 & NS & 2.2 \\
\hline
\end{tabular}

may cause these influences in cucumber plants. Similar results were obtained by Enan et al. (2016) on sugar beet and El-Sayed et al. (2018) on tomato.

Insignificant differences were found among all treatments over the control, in the number of days to flowering in both seasons. This indicated that all algal treatments had no effect on earliness. Fruit set percentage showed a significant enhancement in the biological treatments, specially Amphora (spray + soil drench), which had 75 and $72 \%$, while the chemical nematicide gave 71 and $69 \%$ in the first and second seasons, respectively. Ahmed and Shalaby (2012) recorded the seaweed extracts of green and red algae or commercial seaweed extract (Algreen), as suitable applications to improve vegetative growth and yield of cucumber. Furthermore, similar results were obtained by Youssef and Ali (1998) on cowpea, Shawky et al. (2009) on cucumber, and El-Sayed et al. (2018) on tomato.

Data in Table 3 indicated significant differences among all treatments and control in early and total yields as a number and weight of fruits per plant or per greenhouse, in addition to the marketable yield and the percentage of unmarketable yield in both seasons. The fruit yield was significantly higher in the average fruit weight and the number of fruits per plant by using Amphora (spray + soil drenched). For instance, the total marketable yield with Amphora (spray + soil drench) was 2.5 and 2.69 folds the control in 2016 and 2017 seasons, respectively.

Also, the cucumber marketable yield of Amphora (spray + soil drench) treatment gave 1.18 and 1.11 folds the Rugby nematicide treatment in the first and second seasons, respectively. While the marketable yield of cucumber plants treated with Spirulina (spray + soil drench) gave 2.17 and 2.37 folds the control in both seasons, respectively. The cucumber plants treated with
Rugby nematicide had 1.02 and 0.98 folds the Spirulina (spray + soil drench) in both seasons 2016 and 2017, respectively. But Amphora soil drenched treatment had 4.436 tons per greenhouse, with about 256-kg increase in margin than the cucumber plants treated with Rugby nematicide, which gave 4.180 tons in the first season and 4.615 tons by a margin of $2 \mathrm{~kg}$ than cucumber plants treated with Rugby nematicide, which gave 4.612 tons in the second season. These results may be due to the effects of other growth factors in the composition of algae extract such as phytohormones, prohormones, amino acids, and fatty acids, in addition to the algae extraction which is considered as a large storage of mineral nutrients. All algal extraction components increased the photosynthetic pigments, maximizing the storage of carbohydrates and starch and increasing the cucumber yield and its components. Furthermore, algae contain some antioxidants, polyphenols, flavonoids, and other compounds which resist the nematodes, limiting their spread and reducing their harmful effects as reported by Shawky et al. (2009).

The treatments included both foliar and drench applications at the same time such as Amphora and Spirulina spray with drench which had the best effect. Spraying algae had effects of encouraging to achieve the growth of plants by more compounds such as prohormones or phytohormones, and effects of amino acids, fatty acids, and other protein compounds such as lipids and peptides and mineral nutrition in chelate compounds that led to increased plant growth and produced healthy plants, which reflect on high yield and better quality. In addition, the lethal effects gave a harmful effect to the second generation of nematodes, followed by decreasing the juveniles and reducing the gall and egg formation, which resulted from the presence of compounds similar 
Table 3 Effect of algal treatments of cucumber Hesham hybrid compared with control and Rugby nematicide on early and total, marketable yield and unmarketable yield percentage under infested soil with root-knot nematodes in 2016 and 2017 seasons

\begin{tabular}{|c|c|c|c|c|c|c|c|c|c|c|c|c|}
\hline \multirow{3}{*}{ Treatments } & \multicolumn{6}{|l|}{2016} & \multicolumn{6}{|l|}{2017} \\
\hline & \multicolumn{2}{|c|}{ Yield/Plant } & \multicolumn{2}{|c|}{ Early Yield/Plant } & \multirow{2}{*}{$\begin{array}{l}\text { Marketable } \\
\text { yield (ton/ } \\
\text { Greenhouse) }\end{array}$} & \multirow{2}{*}{$\begin{array}{l}\text { Unmarketable } \\
(\%)\end{array}$} & \multicolumn{2}{|c|}{ Yield/Plant } & \multicolumn{2}{|c|}{ Early Yield/Plant } & \multirow{2}{*}{$\begin{array}{l}\text { Marketable } \\
\text { Yield (ton/ } \\
\text { Green house) }\end{array}$} & \multirow{2}{*}{$\begin{array}{l}\text { Unmarketable } \\
(\%)\end{array}$} \\
\hline & Number & $\begin{array}{l}\text { Weight } \\
(\mathrm{kg})\end{array}$ & Number & $\begin{array}{l}\text { Weight } \\
\text { (g) }\end{array}$ & & & Number & $\begin{array}{l}\text { Weight } \\
(\mathrm{kg})\end{array}$ & Number & $\begin{array}{l}\text { Weight } \\
\text { (g) }\end{array}$ & & \\
\hline Control & 21 & 2.150 & 2.21 & 215.3 & 1.970 & 8.38 & 20 & 2.095 & 3.1 & 312.3 & 1.906 & 9.01 \\
\hline Rugby $10 \mathrm{G}$ & 37 & 4.431 & 5.30 & 634.9 & 4.180 & 5.66 & 41 & 4.874 & 5.5 & 653.8 & 4.612 & 5.38 \\
\hline $\begin{array}{l}\text { Spirulina } \\
\text { spray }\end{array}$ & 27 & 3.229 & 5.00 & 598.0 & 3.107 & 3.76 & 30 & 3.214 & 4.8 & 578.2 & 3.423 & 5.28 \\
\hline $\begin{array}{l}\text { Spirulina } \\
\text { drench }\end{array}$ & 34 & 4.375 & 5.21 & 670.5 & 4.102 & 6.25 & 36 & 3.405 & 5.3 & 648.5 & 4.158 & 5.61 \\
\hline $\begin{array}{l}\text { Amphora } \\
\text { spray }\end{array}$ & 30 & 3.695 & 5.62 & 692.4 & 3.462 & 6.31 & 34 & 4.464 & 5.3 & 695.9 & 4.248 & 4.84 \\
\hline $\begin{array}{l}\text { Amphora } \\
\text { drench }\end{array}$ & 38 & 4.714 & 5.83 & 722.9 & 4.436 & 5.89 & 41 & 4.647 & 5.6 & 662.0 & 4.615 & 4.78 \\
\hline $\begin{array}{l}\text { Spirulina } \\
\text { spray }+ \\
\text { drench }\end{array}$ & 35 & 4.505 & 5.81 & 747.7 & 4.280 & 5.00 & 41 & 4.626 & 5.4 & 625.1 & 4.510 & 4.98 \\
\hline $\begin{array}{l}\text { Amphora } \\
\text { spray + } \\
\text { drench }\end{array}$ & 42 & 5.168 & 6.24 & 767.5 & 4.923 & 4.74 & 45 & 4.981 & 5.9 & 721.5 & 5.136 & 4.56 \\
\hline LSD at t 0.05 & 3.8 & 0.311 & 1.23 & 46 & 1.120 & 1.43 & 4.1 & 0.521 & 1.11 & 55 & 1.44 & 1.87 \\
\hline
\end{tabular}

to nematicides such as flavonoids, polyphenols, phenylalanine, and antioxidants. This effect is confirmed by Youssef and Eissa (2014) who reported that Azolla, Anabaena symbiosis Nostoc, Anabaena, Oscillatoria, Aulosira, and Lyngbya play an important role of fixing atmospheric nitrogen and supplying vitamin B complex and growth-promoting substances.

On the other hand, the percentage of unmarketable yield was decreased by Amphora (spray + drench) treatment, followed by Spirulina drench in the first season giving $3.76 \%$ compared with the percentages of unmarketable yield of control plants that gave $8.38 \%$ and $9.1 \%$ in both seasons, respectively. These results may be due to the highest amounts of amino acids and total protein contents in both algae. These results agree with those of Ahmed and Shalaby (2012) who recorded the highest amounts of amino acid, fatty acid, and polypeptides in algae extract, which improved the fruit quality.

Table 4 Effect of algal treatments of cucumber Hesham hybrid compared with control and Rugby nematicide on fruit characters, total soluble solids, and NPK under infested soil with root-knot nematodes in 2016 and 2017 seasons

\begin{tabular}{|c|c|c|c|c|c|c|c|c|c|c|c|c|c|c|c|c|}
\hline \multirow{3}{*}{ Treatments } & \multicolumn{8}{|c|}{2016} & \multicolumn{8}{|c|}{2017} \\
\hline & \multirow{2}{*}{$\begin{array}{l}\text { Fruit } \\
\text { weight } \\
\text { (g) }\end{array}$} & \multicolumn{2}{|c|}{ Fruit $(\mathrm{cm})$} & \multirow{2}{*}{ T.S.S } & \multirow{2}{*}{$\begin{array}{l}\text { Fruit dry } \\
\text { matter (\%) }\end{array}$} & \multicolumn{3}{|c|}{ Minerals } & \multirow{2}{*}{$\begin{array}{l}\text { Fruit } \\
\text { weight } \\
\text { (g) }\end{array}$} & \multicolumn{2}{|c|}{ Fruit } & \multirow{2}{*}{ T.S.S } & \multirow{2}{*}{$\begin{array}{l}\text { Fruit dry } \\
\text { matter (\%) }\end{array}$} & \multicolumn{3}{|c|}{ Minerals (\%) } \\
\hline & & Length & Diameter & & & $\mathrm{N}$ & $P$ & K & & Length & Diameter & & & $\mathrm{N}$ & P & K \\
\hline Control & 102.4 & 14.6 & 2.2 & 4.2 & 5.2 & 1.414 & 0.20 & 1.13 & 104.75 & 13.8 & 2.4 & 4.6 & 4.9 & 1.325 & 0.23 & 1.24 \\
\hline Rugby $10 \mathrm{G}$ & 119.8 & 17.6 & 2.8 & 4.2 & 4.8 & 3.257 & 0.46 & 3.09 & 118.878 & 17.21 & 2.9 & 4.6 & 4.7 & 3.39 & 0.39 & 2.78 \\
\hline Spirulina spray & 119.6 & 17.8 & 2.8 & 4.4 & 4.6 & 2.114 & 0.30 & 4.12 & 120.467 & 16.98 & 3 & 4.5 & 4.7 & 2.451 & 0.32 & 3.96 \\
\hline $\begin{array}{l}\text { Spirulina } \\
\text { drench }\end{array}$ & 128.7 & 17.8 & 2.7 & 4.2 & 4.7 & 3.052 & 0.447 & 2.97 & 122.361 & 17.4 & 2.9 & 4.5 & 4.8 & 3.292 & 0.39 & 2.37 \\
\hline Amphora spray & 123.2 & 17.5 & 3.1 & 4.2 & 4.5 & 3.283 & 0.335 & 3.62 & 131.294 & 17.5 & 3.2 & 4.5 & 4.7 & 3.415 & 0.36 & 3.54 \\
\hline $\begin{array}{l}\text { Amphora } \\
\text { drench }\end{array}$ & 124.0 & 18.4 & 3.2 & 4.3 & 4.6 & 3.433 & 0.540 & 4.91 & 118.22 & 17.2 & 3.2 & 4.4 & 4.8 & 3.79 & 0.48 & 4.34 \\
\hline $\begin{array}{l}\text { Spirulina spray } \\
+ \text { drench }\end{array}$ & 128.7 & 17.8 & 3.1 & 4.3 & 4.4 & 2.534 & 0.415 & 3.63 & 115.756 & 18.1 & 2.8 & 4.6 & 4.9 & 3.14 & 0.45 & 3.48 \\
\hline $\begin{array}{l}\text { Amphora } \\
\text { spray + drench }\end{array}$ & 123.0 & 18.8 & 3.2 & 4.6 & 4.2 & 4.216 & 0.542 & 3.51 & 122.295 & 17.8 & 2.9 & 4.6 & 4.8 & 4.156 & 0.56 & 4.68 \\
\hline LSD at t 0.05 & 7.400 & 1.32 & 0.4 & NS & NS & 0.654 & 0.121 & 0.54 & 12.45 & 2.31 & 0.3 & NS & NS & 0.461 & 0.10 & 0.514 \\
\hline
\end{tabular}


Data presented in Table 4 indicated that Amphora (spray + drench) treatment showed a significant increase in most of the fruit characteristics. Regarding mineral concentrations, nitrogen, phosphorus, and potassium, Amphora (spray + drench) showed a significant increase compared to Rugby and control for this trait. The results could be due to the algae's large amounts of mineral nutrients (Marrez et al. 2014). On the other hand, data showed insignificant differences between all treatments and control for the total soluble solid and fruit dry matter. These results agree with those of Youssef and Eissa (2014) who reported an increase of $10-30 \%$ in paddy rice and suppression in weed growth caused by Azolla. Furthermore, Marrez et al. (2014) reported that Spirulina is a rich source of potassium (K) and contains considerable amounts of $\mathrm{Ca}, \mathrm{Cu}, \mathrm{Fe}, \mathrm{Mg}$, $\mathrm{Mn}, \mathrm{P}$, and $\mathrm{Zn}$; hence, it increases uptake and accumulation of these elements in plants. This in turn explains the significant increase of vegetative growth and yield and its components (Enan et al. 2016).

\section{Effect of algal treatments on nematode control}

Data presented in Table 5 summarize significant differences in all nematode parameters at different treatments compared with control. Control (untreated) plants exhibited a high gall formation in the two seasons; on the other hand, Rugby nematicide and Amphora (spray + drench) treatments caused the lowest gall numbers compared to the control plants. Differences in numbers of galls in the first season and egg masses in both seasons between Rugby and Amphora (spray+ drench) were insignificant. Applications of various algal treatments suppressed $M$. incognita population on cucumber. The effectiveness of the treatments was expressed by reducing the number of galls on the root system and the final nematode number in soil (final population). These results may be due to the huge amount of secondary metabolites and bionematicides, which are produced by algae (Amphora and Spirulina) such as phenols, antioxidant, polyphenols, and flavonoids. A similar conclusion was mentioned by Gervick et al. (2001) that the blue-green alga, such as S. platensis, produce components that had a nematicidal effect. Amphora may produce high amounts of these products than Spirulina, which explains its superiority in nematode resistance. Similarly, Khan et al. (1997) reported that the efficacy of culture filtrates of the cyanobacterium against egg hatching and mortality of $M$. incognita was dependent on its concentration and period of exposure. The high mortality percentages recorded for nematode juveniles exposed to the algal culture filtrates may be due to the presence of some phenolic compounds and mineral salts that facilitate and accelerate the rate of penetration of algal byproducts through a snail's skin, hence increasing their harmful effects (Mahmoud 2001). Moreover, Radwan et al. (2012) concluded that microbial products are one of the components in integrated root-knot nematode management on tomatoes. In this respect, Youssef and Ali (1998) and Pushparaj et al.

Table 5 Effect of algal treatments of cucumber Hesham hybrid compared with control and Rugby nematicide on the galls, egg masses, eggs, rate of buildup, and number of larvae in infested soil with root-knot nematodes in 2016 and 2017 seasons

\begin{tabular}{|c|c|c|c|c|c|c|c|c|c|c|c|c|}
\hline \multirow[b]{2}{*}{ Treatments } & \multicolumn{6}{|l|}{2016} & \multicolumn{6}{|l|}{2017} \\
\hline & $\begin{array}{l}\text { No. of } \\
\text { larvae in } \\
100 \mathrm{~g} \\
\text { Soil }\end{array}$ & $\begin{array}{l}\text { No. of } \\
\text { galls/ } \\
\text { root } \\
\text { system }\end{array}$ & $\begin{array}{l}\text { No. of } \\
\text { egg } \\
\text { mass/root } \\
\text { system }\end{array}$ & $\begin{array}{l}\text { No. of } \\
\text { egg/ } \\
\text { egg } \\
\text { mass }\end{array}$ & $\begin{array}{l}\text { No. } \\
\text { eggs/ } \\
\text { root } \\
\text { system }\end{array}$ & $\begin{array}{l}\text { Reproduction } \\
\text { factor (RF) }\end{array}$ & $\begin{array}{l}\text { No. of } \\
\text { larvae in } \\
100 \mathrm{~g} \\
\text { Soil }\end{array}$ & $\begin{array}{l}\text { No. of } \\
\text { galls/ } \\
\text { root } \\
\text { system }\end{array}$ & $\begin{array}{l}\text { No. of } \\
\text { egg } \\
\text { mass/root } \\
\text { system }\end{array}$ & $\begin{array}{l}\text { No. of } \\
\text { eggs/ } \\
\text { egg } \\
\text { mass }\end{array}$ & $\begin{array}{l}\text { No. of } \\
\text { eggs/ } \\
\text { egg } \\
\text { system }\end{array}$ & $\begin{array}{l}\text { Reproduction } \\
\text { factor (RF) }\end{array}$ \\
\hline Control & 14,622 & 409 & 112 & 39 & 4368 & 1.035 & 14,516 & 345 & 198 & 40 & 7920 & 1.05 \\
\hline Rugby $10 G$ & 3890 & 48 & 21 & 6 & 126 & 0.275 & 4294 & 55 & 26 & 7 & 182 & 0.31 \\
\hline $\begin{array}{l}\text { Spirulina } \\
\text { spray }\end{array}$ & 13,751 & 301 & 98 & 32 & 3136 & 0.97 & 13,909 & 291 & 105 & 37 & 3885 & 1.01 \\
\hline $\begin{array}{l}\text { Spirulina } \\
\text { drench }\end{array}$ & 7396 & 128 & 62 & 28 & 1736 & 0.52 & 8277 & 150 & 72 & 27 & 1944 & 0.60 \\
\hline $\begin{array}{l}\text { Amphora } \\
\text { spray }\end{array}$ & 13,800 & 254 & 87 & 26 & 2262 & 0.98 & 13,472 & 277 & 98 & 33 & 3234 & 0.98 \\
\hline $\begin{array}{l}\text { Amphora } \\
\text { drench }\end{array}$ & 5373 & 149 & 53 & 22 & 1166 & 0.38 & 7178 & 112 & 43 & 19 & 988 & 0.52 \\
\hline $\begin{array}{l}\text { Spirulina } \\
\text { spray + } \\
\text { drench }\end{array}$ & 8400 & 126 & 56 & 19 & 1064 & 0.59 & 8184 & 132 & 52 & 30 & 1290 & 0.59 \\
\hline $\begin{array}{l}\text { Amphora } \\
\text { spray + } \\
\text { drench }\end{array}$ & 5940 & 77 & 33 & 9 & 297 & 0.42 & 6127 & 98 & 29 & 8 & 232 & 0.45 \\
\hline $\begin{array}{l}\text { LSD at t } \\
0.05\end{array}$ & 1682 & 33 & 20 & 5 & 78 & 0.14 & 1509.6 & 26 & 17 & 4 & 89 & 0.15 \\
\hline
\end{tabular}


Table 6 Means of galls, egg mass, and egg number reductions compared with control at different treatments in 2016 and 2017 seasons

\begin{tabular}{|c|c|c|c|c|c|c|}
\hline \multirow[t]{2}{*}{ Treatments } & \multicolumn{3}{|l|}{2016} & \multicolumn{3}{|l|}{2017} \\
\hline & Gall reduction\% & Egg masses reduction\% & Eggs reduction\% & Gall reduction\% & Egg masses reduction\% & Eggs reduction\% \\
\hline Rugby 10G & 88.26 & 81.25 & 97.12 & 84.05 & 86.86 & 97.70 \\
\hline Spirulina spray & 26.40 & 12.50 & 28.20 & 15.65 & 46.97 & 50.95 \\
\hline Spirulina drench & 68.70 & 44.64 & 60.26 & 56.52 & 63.64 & 75.45 \\
\hline Amphora spray & 37.89 & 22.32 & 48.21 & 19.70 & 50.51 & 59.16 \\
\hline Amphora drench & 63.56 & 52.68 & 73.30 & 67.50 & 78.28 & 87.52 \\
\hline Spirulina spray + drench & 69.19 & 50.00 & 75.64 & 61.74 & 73.74 & 83.70 \\
\hline Amphora spray + drench & 81.17 & 70.53 & 93.20 & 71.59 & 85.35 & 97.07 \\
\hline
\end{tabular}

(2000) reported that the blue-green algae reduced the number of galls and egg masses of the root-knot nematode-infected cowpea and tomato plants, respectively.

Variation in the number of eggs between the two treatments, Rugby and Amphora (spray + drench), in the first season was significant. Egg production fitness was always correlated with untreated plants (control), while this ability decumbently degenerated with the Rugby and Amphora (spray + drench).

With respect to algal treatments in Table 5, the numbers of galls, egg masses, and eggs in addition to RF values, obtained through the two seasons, greatly differed and the differences were statistically significant than that of the control. In contrast, control plants supported the highest rates of nematode reproduction (RF), while the Rugby treatment supported the lowest rate. Reproductive values of Meliodogyne spp. greatly varied among all the treatments and control. The nematodes reproduced efficiently on the control plants, whereas reproductions on the treated plants were not efficient.

Control plants exhibited a high degree of nematode infection, egg-mass formation, and egg deposition; this indicated that the final nematode population $(14,622$ and 14,516) increased over the initial nematode populations $(13,752$ and 14,124). Reproductive values of nematodes were significantly different between control plants and all treatments. RF values of the Rugby were 0.31 and 0.275 , while they were 1.05 and 1.035 on the control in the two seasons, respectively. Some of the tested algal treatments possessed nematicidal effects that may be released in the soil. In addition, these treatments of algae may produce compounds, such as asetamide, hexamethyl, methoxyphenyl, phenol, and others, which are normally toxic to the root-knot nematode. All the tested products significantly reduced the numbers of juveniles in soil and galls, females, and egg masses on roots. Also, these products suppressed egg hatching.

Data presented in Table 6 show percentages of reduction in gall, egg mass, and egg numbers of the six algal treatments and chemical nematicide (Rugby) compared with the control. Data were confirmed at all parameters, whereas percentages of reduction in gall numbers in the first and the second seasons for Rugby nematicide were 88.26 and $84.05 \%$, recording the highest gall reduction in both seasons, respectively. These results are near to those of Amphora (spray+ drench) treatments, which were 81.17 and $71.59 \%$. Concerning Amphora (spray + drench) treatment, percentages of reduction of egg masses were 70.53 and 85.35 and egg numbers were 93.20 and $97.07 \%$, while the percentages of reduction in Rugby nematicide were 81.25 and 86.86 for egg masses and 97.12 and 97.070 for eggs in both seasons, respectively.

These results confirm that the bio-management could be an alternative strategy to the chemical approach. These results agree with that of Sharma and Gaur (2008) who studied the effects of extracts and exudates of five cyanobacteria, autotrophic blue-green algae, on the hatching of $M$. incognita.

\section{Conclusion}

This study demonstrated that the most tested algal treatments significantly reduced root-knot nematode numbers, specially Amphora (spray + soil drench) treatment that showed the highest suppression effects on the root-knot nematode. Furthermore, this treatment enhanced plant growth than the other applications. The foliar and soil drench application should be used.

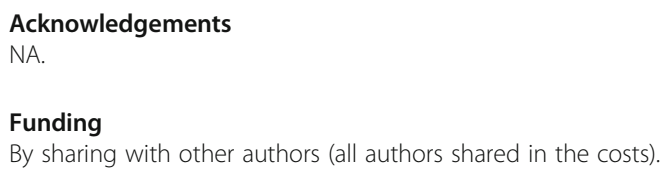

Availability of data and materials

All datasets are presented in the main manuscript.

Authors' contributions

All authors read and approved the final manuscript.

Authors' information

As mentioned above. 
Ethics approval and consent to participate

Not applicable.

\section{Consent for publication}

Not applicable.

\section{Competing interests}

The authors declare that they have no competing interests.

\section{Publisher's Note}

Springer Nature remains neutral with regard to jurisdictional claims in published maps and institutional affiliations.

\section{Author details}

${ }^{1}$ Vegetable Crops Production under Protected Cultivation Research Department, Horticulture Research Institute ARC, 1 Shooting Club St., Dokki, Giza, Egypt. 'Faculty of Agriculture, Zoology and Nematology Department, Cairo University, Cairo University St., Giza, Egypt.

Received: 15 November 2018 Accepted: 15 March 2019

Published online: 02 April 2019

\section{References}

Ahmed YM, Shalaby EA (2012) Effect of different seaweed extracts and compost on vegetative growth, yield and fruit quality of cucumber. J Hortic Sci Ornament Plants 4(3):235-240

AOAC, Association of Official Analytical Chemists (2012). Official Methods of Analysis of the AOAC International No. 994.12. Chapter 4, p.18-19.19th Edn, Revision. $19^{\text {th }}$ Chapter 4, 18-19, Official Journal of the European Communities 19.9.98, Gaithersburg, Maryland, USA

Brown JG, Lilleland O (1946) Rapid determination of potassium and sodium in plant materials and soil extracts by flame photometer. Proc Am Soc Hortic Sci 48:341-346

Chtourou H, Dahmen I, Jebali A, Karray F, Hassairi I, Abdelkafi S, Ayadi H, Sayadi S, Dhouib A (2015) Characterization of Amphora sp., a newly isolated diatom wild strain, potentially usable for biodiesel production. Bioprocess Biosyst Eng 38(7):1381-1392

Collange B, Navarretea M, Peyrea G, Mateilleb T, Tchamitchian M (2011) Rootknot nematode (Meloidogyne) management in vegetable crop production: The challenge of an agronomic system analysis. Crop Prot 30(10):1251-1262

El-Sayed AB, Shehata SA, Taha, Sahar S, Hamouda HA, Abdelgawad Karima F, Youssef Doaa M (2018) Algae extract overcoming the adverse effects of saline stress in hydroponic grown tomato plants. J Food Agric Environ 16(2):92-99

Enan SAAM, El-Saady AM, El-Sayed AB (2016) Impact of foliar feeding with alga extract and boron on yield and quality of sugar beet grown in sandy soil. Egypt J Agronematol 38(2):319-336

Franklin MT, Goodey JB (1959) A cotton-blue lactophenol technique for counting plant parasitic nematodes. J Helminthol 23:175-178

Gervick WH, Tan LT, Siachitta N (2001) In: Cordell G (ed) The alkaloids, vol 57. Academic Press, San Diego, pp 75-184

Ghalab AM, Salem SA (2001) Effect of bio-fertilizer treatments on growth, chemical composition and productivity of wheat grown under different levels of NPK fertilization. Ann Agric Sci 46:485-509

Gomez KA, Gomez AA (1984) Statistical procedures for agricultural research. Wiley, New York, p 680

John MK (1970) Colorimetric determination of phosphorus in soil and plant material with ascorbic acid. Soil Sci 109:214-220

Khan Z, Jairajpuri MS, Khan MW (1997) Effect of culture filtrate of a blue-green alga Microcoleus vaginatus on mortality and hatching of root-knot nematode Meloidogyne incognita. Int J Nematol 7:100-102

Lee SH, Karawita R, affan A, Lee JB, Lee BJ, Jeon YJ (2008) Potential antioxidant activates of enzymatic digests from Benthic diatoms, Achnanthes longipes, Amphora coffeaeformis, and Navicula sp. (Bacillariophyceae). J Food Sci Nutr 12:166-175

Mahmoud MB (2001) Physiological studies on Biomphalaria alexandrina snails and their susceptibility to Schistosoma mansoni infection. Ph.D. Thesis, Faculty of Science, Ain Shams University, Cairo

Marrez DA, Naguib MM, Sultan YY, Daw ZY, Higazy AM (2014) Evaluation of chemical composition for Spirulina platensis in different culture media. Res $J$ Pharm, Biol Chem Sci 5(4):1161-1171
Massa NB (2010) The use of seaweed-based products from Ecklonia maxima and Ascophyllum nodosum as control agents for Meloidogyne chitwoodi and M. hapla on tomato plants. Netherlands: Faculty of Science, Gent University; p 29.

Murphy J, Riely JP (1962) A modified single solution method for the determination of phosphorus in natural waters. Anal Chim Acta 27:31-36

Pregl F (1945) Quantitative organic micro-analysis, 4th edn. J. and A. Churchill Ltd, London, pp 203-209

Pushparaj B, Pelosi E, Caroppo S (2000) Effect of Nodularia harveyana biomass on the incidence of root-knot nematode, Meloidogyne incognita in tomato. J Appl Phycol 12:489-492

Radwan MA, Farrag SAA, Abu-Elamayem MM, Ahmed NS (2012) Biological control of root-knot nematode, Meloidogyne incognita on tomato using bioproducts of microbial origin. Appl Soil Ecol 56:58-62

Sharma HK, Gaur HS (2008) Hatch inhibition of Meloidogyne incognita by aqueous extracts and exudates of five species of cyanobacteria. Nematol Mediterr 36:99-102

Shawky SM, Mostafa SSM, Abd El-AllA AM (2009) Efficacy of algae, azolla and compost extract in controlling root knot nematode and its reflection on cucumber growth. Bull Fac Agric Univ Cairo 60:443-459

Sikora RA, Fernández E (2005) Nematode parasites of vegetables. In: Sikora LM, Bridge RAJ (eds) Plant parasitic nematodes in subtropical and tropical agriculture. CABI, Wallingford, pp 319-392

Viglierchio DR, Schmitt RV (1983) On the methodology of nematode extraction from field samples: baermann funnel modifications. J Nematol 15(3):438-440

Wu Y, Jenkins T, Blunden G, Whapham C, Hankins SD (1997) The role of betaines in alkaline extracts of Ascophyllum nodosum in the reduction of Meloidogyne javanica and $M$. incognita infestations of tomato plants. Fundam Appl Nematol 20:99-102

Yadava UL (1986) A rapid and non-destructive method to determine chlorophyll in intact leaves. HortScience 21:1149-1450

Yassen AA, Badran NM, Zaghloul SM (2007) Role of some organic residues as tools for reducing metals hazard in plant. World J Agric Sci 3(2):204-209

Youssef MMA, Ali MS (1998) Management of Meloidogyne incognita infecting cowpea by using some native blue green algae. Anzeiger für Schädlingskunde, Pflanzenschutz, Umweltschutz 71:15-16

Youssef MMA, Eissa MFM (2014) Biofertilizers and their role in management of plant parasitic nematodes. A review. J Biotechnol Pharm Res 5(1):001-006

\section{Submit your manuscript to a SpringerOpen ${ }^{\oplus}$ journal and benefit from:}

- Convenient online submission

- Rigorous peer review

- Open access: articles freely available online

- High visibility within the field

- Retaining the copyright to your article

Submit your next manuscript at $\boldsymbol{\nabla}$ springeropen.com 